\title{
Faktor-Faktor Yang Mempengaruhi Keputusan Petani Dalam Pemanfaatan Lahan Rawa Lebak Pada Usahatani Padi Sawah Di Desa Pasar Terusan Kecamatan Muara Bulian Kabupaten Batanghari
}

\author{
Heru Permana ${ }^{1)}$, Fendria Sativa ${ }^{2)}$ dan Pera Nurfathiyah ${ }^{2)}$
}

1) Alumni Program Studi Agribisnis Fakultas Pertanian Universitas Jambi,

2) Dosen Program Studi Agribisnis Fakultas Pertanian Universitas Jambi

Email:e_you_densus89@yahoo.co.id

\begin{abstract}
ABSTRAK
Penelitian ini bertujuan Untuk mengetahui faktor yang mempengaruhi keputusan petani dalam pemanfaatan lahan rawa lebak di Desa Pasar Terusan Kecamatan Muara Bulian Kabupaten Batanghari dan untuk mengetahui faktor apa yang mempengaruhi keputusan petani dalam pemanfaatan lahan rawa lebak di Desa Pasar Terusan Kecamatan Muara Bulian Kabupaten Batanghari. Penelitian ini di laksanakan pada tanggal 10 juni 2013 - 10 juli 2013 di Desa Pasar terusan Kecamatan Muara Bulian Kabupaten Batanghari. Pengumpulan data dalam penelitian ini terdiri dari data primer dan data skunder. Metode penarikan sampel menggunakan metode sensus (Sampling Jenuh). Data yang diperoleh dari petani sampel disederhanakan dalam tabel kontingensi kemudian dianalisis secara deskriptif melalui skoring dan persentase, sedangkan untuk mengetahui pengaruh faktor-faktor petani terhadap keputusan petani dalam pemanfaatan lahan rawa lebak menggunakan uji ZScore. Hasil penelitian menunjukkan bahwa berdasarkan analisis deskriptif, bahwa faktor pengalaman petani, tidak terdapat kecenderungan pengaruh terhadap pengambilan keputusan petani dalam pemanfaatan lahan rawa lebak pada usahatani padi sawah, sedangkan faktor kebiasaan dan kemauan,faktor pengetahuan, dan faktor motif ekonomi terdapat kecenderungan pengaruh terhadap pengambilan keputusan petani dalam pemanfaatan lahan rawa lebak pada usahatani padi sawah di daerah penelitian. Hasil dari Uji Zscore Faktor yang mempengaruhi keputusan petani dalam pemanfaatan lahan rawa lebak pada usahatani padi sawah yang dominan adalah faktor motif ekonomi.
\end{abstract}

Kata Kunci : Keputusan petani, Lahan rawa lebak, Padi Sawah

\section{ABSTRACT}

The purpose of this research is to find out what factor that influence farmers' decision in utilizing the swampy wetlands for rice field at Pasar Terusan Village Muara Bulian District Batanghari Regency and to find out what factor that influencing farmers' decision in utilizing the swampy wetlands for rice field at Pasar Terusan Village Muara Bulian District Batanghari Regency. This research held at June 10th, 2013-July 10th, 2013 at Pasar Terusan Village Muara Bulian District Batanghari Regency. The data on this research consist of primer data and secondary data. The technique for collecting the sample is applying census method (Sapling Jenuh). The sample data from the farmer are simplified in contingency table and then analyzed descriptively through scoring and percentage, whereas to find out the farmers' 
factors toward utilizing the swampy wetlands is using Zscore test. The results showed that based on descriptive analysis, that farmers experience factor, there is a tendency to influence the decision making of farmers in the swampy marsh land use in lowland rice farming, while the habits and willingness factors, knowledge factors, and there is a tendency of economic motives factors influence the decision making farmers in the swampy marsh land use in lowland rice farming in the study area. The result of Zscore test is the factor that influencing the farmers in making the decision to utilize the swampy wetlands for rice field farming is the dominant economic motives factor.

\section{Keywords: farmers' decision, swampy wetlands, wetland rice}

\section{PENDAHULUAN}

Pangan sebagai kebutuhan pokok manusia senantiasa memiliki tingkat permintaan yang tinggi seiring dengan meningkatnya jumlah penduduk. Semakin banyak penduduk di suatu wilayah permintaan pangan akan semakin tinggi. Meningkatnya kebutuhan pangan akibat bertambahnya jumlah penduduk menuntut produktivitas dan produksi padi lebih tinggi, mengingat kecepatan peningkatan jumlah penduduk mengikuti deret ukur (Dharmawan, 2010). Memenuhi kebutuhan pangan yang terus menerus meningkat, salah satunya dapat dilakukan dengan peningkatan produktivitas padi sawah melalui pemanfaatan lahan rawa lebak untuk usahatani padi sawah. Perluasan sawah saat ini menjadi andalan dalam usaha peningkatan produktifitas padi di Provinsi Jambi.

Desa Pasar Terusan Kecamatan Muara Bulian merupakan salah satu daerah yang berpotensi untuk lahan persawahan. Oleh karena itu, petani padi sawah di Desa Pasar Terusan, Kecamatan Muara Bulian, masih terus membangun dan memperluas lahan sawah, di tengah maraknya pengalihan lahan sawah menjadi lahan kelapa sawit dan lahan perkebunan lainnya. Petani membuka lahan baru untuk persawahan bukan karena adanya bantuan dari pemerintah, melainkan dibangun secara swadaya.

Keputusan petani dalam pemanfaatan lahan rawa lebak pada berusahatani padi sawah diputuskan oleh petani pemilik biasanya lahan persawahan. Petani dengan status pemilik bebas menentukan kebijaksanaan dalam usahataninya. Petani di Desa Pasar Terusan mempertahankan berusahatani padi sawah ini karena turunan dari nenek moyang terdahulu yang selalu di terapkannya sampai sekarang, karena jika seseorang dalam menerapkan sesuatu hal yang baru, tentu pada dirinya diharapkan adanya sesuatu bentuk bakat (modal dasar) berupa pengetahuan mengenai objek yang akan digeluti. Ancaman krisis pangan di tahun-tahun yang akan datang membuat petani di Desa Pasar Terusan mempertahankan berusahatani padi sawah dan memperluas lahan untuk mempersiapkan krisis pangan yang akan datang. Hal ini sesuai dengan Peraturan Gubernur Jambi Nomor 14 tahun 2009 tentang pencegahan alih fungsi lahan tanaman pangan dan hortikultura untuk pemanfaatan lahan dan Keputusan Bupati Batang Hari Nomor 20/tahun 2011 tentang pembentukan tim teknis lembaga distribusi pangan masyarakat Kabupaten Batang Hari Tahun 2011.

Dalam Keputusan Kepala Desa Pasar Terusan tahun 2012 yang isinya menyatakan bahwa dalam rangka mempertahankan dan meningkatkan pelaksanaan penanaman padi sawah dan padi payo melalui program Intensifikasi tahun 2012 perlu adanya susunan suatu jadwal kegiatan pelaksanaan intensifikasi padi. Keputusan Kepala Desa Pasar Terusan 
tentang kegiatan turun ke humo dengan luas usahataninya kurang lebih 820 hektar. Keputusan Kepala Desa ini mampu menekan krisis pangan di Desa Pasar Terusan khususnya untuk mencukupi kebutuhan beras di lingkup desa.

\section{METODE PENELITIAN}

Penelitian ini dilaksanakan di Desa Pasar Terusan Kecamatan Muara Bulian Kabupaten Batang Hari. Pemilihan lokasi dilakukan secara sengaja (purposive) atau memihak dengan pertimbangan lokasi di Desa Pasar Terusan Kecamatan Muara Bulian mempunyai luas lahan terluas dalam pemanfaatan lahan rawa lebak dibandingkan desa lainnya, sehingga produksi relatif tinggi, hal ini mengindikasikan bahwa rata-rata produksi di daerah ini lebih tinggi dari daerah lainnya di Kabupaten Batanghari. Lingkup penelitian ini adalah mengkaji faktor-faktor yang mepengaruhi keputusan petani yang memanfaatkan lahan rawa lebak untuk kegiatan usahatani padi sawah. Penelitian ini akan dilaksanakan dari tanggal 10 juni sampai 10 juli 2013

Populasi dalam penelitian ini adalah petani padi sawah. Lokasi sampel berada di Desa Pasar Terusan. Penarikan daerah sampel dilakukan secara sengaja (purposive),dengan mempertimbangkan bahwa desa tersebut mengusahakan padi sawah yang memanfaatkan lahan rawa lebak sehingga luas tanam meningkat dan berproduksi tinggi dibandingkan desa yang ada di Kecamatan Muara Bulian Kabupaten Batang hari.

Petani padi yang berusahatani padi sawah Di Desa Pasar Terusan sebanyak 520 KK, sedangkan yang memanfaatkan lahan rawa lebak untuk usahatani padi sawah sebanyak 65 KK, untuk keperluan penelitian ini semua anggota populasi digunakan sebagai respondenyaitu sebanyak 65 KK, dengan menggunakan metode sensus (Sampling Jenuh).

Data yang diperoleh dari hasil penelitian ini dianalisis secara deskriptif dengan menggunakan tabulasi frekuensi dan persentase (\%). Untuk mengetahui faktor-faktor yang mempengaruhi keputusan petani dalam pemamfaatan lahan rawa lebak pada usahatani padi sawah di Desa Pasar Terusan Kecamatan Muara Bulian Kabupaten Batanghari dilakukan uji Z Score (Djarwanto PS, 1987).

Uji Z adalah salah satu uji perbedaan atau pengaruh dari beberapa variabel-variabel yang di teliti yaitu variabel yang mempengaruhi keputusan petani dalam pemanfaatan lahan rawa lebak pada usahatani padi sawah di Desa Pasar Terusan Kecamatan Muara bulian Kabupaten Batanghari, variabel yang di maksud seperti kebiasaan dan kemauan, pengelaman, pengetahuan, dan motif ekonomi. Uji Z pengujian hipotesisnya didekati dengan distribusi normal. Oleh karena itu, uji $Z$ dapat digunakan utuk menguji data yang sampelnya berukuran besar. Jumlah sampel 30 atau lebih dianggap sampel berukuran besar. (Sugiono 2012). 
Tabel 1. Kontingensi Faktor - Faktor yang mempengaruhi keputusan petani dalam pemanfaatan lahan rawa lebak pada usahatani padi sawah

\begin{tabular}{lcccc}
\hline Faktor yang & Keputusan Petani & & \multirow{2}{*}{ Jumlah } \\
\cline { 2 - 4 } $\begin{array}{l}\text { Mempengaruhi } \\
\text { Rendah }\end{array}$ & Rendah & Tinggi & \\
$\begin{array}{l}\text { (<Me) } \\
\text { Tinggi }\end{array}$ & $\mathrm{n}_{11}$ & $\mathrm{n}_{12}$ & $\left(\mathrm{n}_{11}+\mathrm{n}_{12}\right)$ \\
$(>\mathrm{Me})$ & $\mathrm{n}_{21}$ & & \\
& & $\mathrm{n}_{22}$ & $\left(\mathrm{n}_{21}+\mathrm{n}_{22}\right)$ \\
\hline Jumlah & $\mathrm{n}_{11}+\mathrm{n}_{21}$ & & \\
& & $\mathrm{n}_{12}$ & $\mathrm{~N}$ \\
\hline
\end{tabular}

Adapun Uji yang digunakan untuk menguji hipotesis adalah :

Keterangan :

$$
Z_{h i t} \frac{=\left(n_{i j}-P\right)-\frac{1}{2} n}{\sqrt{n \cdot p \cdot Q}}{ }^{2}
$$

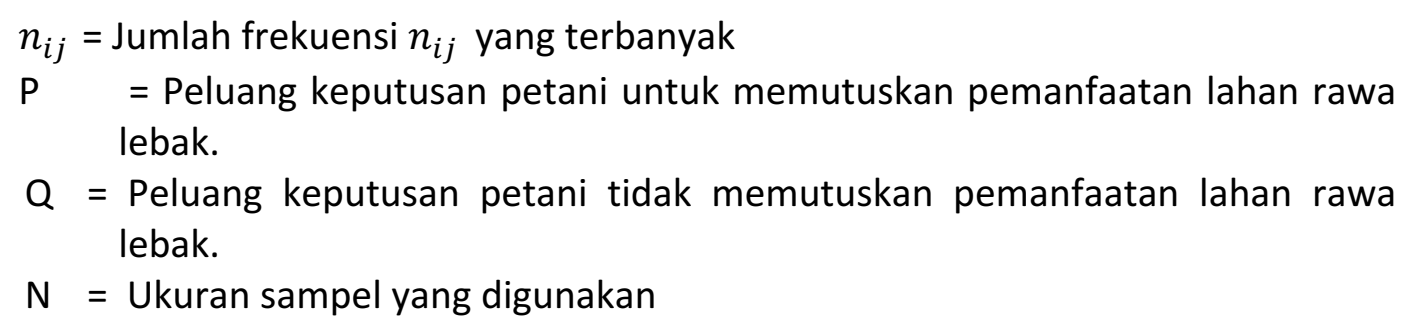

Kriteria pengambilan keputusan yang di uji adalah :

Jika $Z_{\text {hit }}\left[\left(\leq Z_{\text {tab }}(x=5 \% \mathrm{db}=1)\right.\right.$ terima Ho

Jika $Z_{\text {hit }}\left[\left(>Z_{\text {tab }}(x=5 \% d b=1)\right.\right.$ tolak Ho

Dimana :

$\mathrm{H}_{0} ; \mathrm{Me}=0$

$\mathrm{H}_{1} ; \mathrm{Me} \neq 1$

Keterangan :

$\mathrm{H}_{0}=$ Kemauan dan kebiasaan,pengalaman,pengetahuan, dan motif ekonomi,secara bersama-sama tidak mempengaruhi keputusan petani dalam pemanfaatan lahan rawa lebak pada usahatani padi sawah

$\mathrm{H}_{1}=$ Kemauan dan kebiasaan, pengalaman,pengetahuan, dan motif ekonomi,secara bersamasama mempengaruhi keputusan petani dalam pemanfaatan lahan rawa lebak pada usahatani padi sawah

\section{HASIL DAN PEMBAHASAN}

Analisis Faktor-Faktor Yang Mempengaruhi Keputusan Petani Dalam Pemanfaatan Lahan rawa lebak.

\section{Kebiasaan Dan Kemauan}

Kebiasaan dan kemauan adalah salah satu faktor dalam pemanfaatan lahan rawa lebak pada usahatani padi sawah, keputusan petani dalam pemanfaatn lahan rawa lebak untuk 
usahatani padi sawah karena melihat kebiasaan dari dulu yang turun menurun terus memperluas areal persawahan dan di tambah dorongan kemauan diri-sendiri petani tanpa ada paksaan dari siapapun. Untuk lebih jelas dapat dilihat pada Tabel 2.

Tabel 2.Kontingensi Pengaruh Faktor Kebiasaan Dan Kemauan Terhadap Keputusan Petani Dalam Pemanfaatan Lahan rawa lebak Pada Usahatani Padi Sawah Di Daerah Penelitian 2013

\begin{tabular}{|c|c|c|c|c|}
\hline \multirow[t]{2}{*}{ Kebiasan dan Kemauan } & $\begin{array}{l}\text { Keputusan } \\
\text { rawa lebak }\end{array}$ & Petani & Memanfaatkan lahan & \multirow[t]{2}{*}{ Total } \\
\hline & Rendah & & Tinggi & \\
\hline Rendah & 7 & & 20 & 27 \\
\hline Tinggi & 11 & & 27 & 38 \\
\hline Jumlah & 18 & & 47 & 65 \\
\hline
\end{tabular}

Tabel 2 pengaruh faktor kebiasaan dan kemauan terdapat kecendrungan dalam mamanfaatkan lahan rawa lebak untuk usahatani padi sawah di karenakan, dilihat dari sampel yang tertinggi terdapat 27 petani sampel yang menjawab faktor kebiasaan dan kemauan dengan kategori tinggi sedangkan keputusan petani dengan rata-rata rendah

Menurut Ahmadi dan supriono (2004) kebiasaan merupakan perbuatan yang dilakukan secara berulang-ulang. Sehingga keputusan petani dalam faktor kebiasaan ini karena ingin mempertahankan kebiasaan dari nenek moyang yang bertani padi sawah.Kemauan adalah didasarkan atau terjadi karena adanya dorongan yang kuat dari dalam diri petani tersebut dalam pengambilan keputusan.

Selanjutnya dijelaskan oleh Soekanto (1982), kebiasaan merupakan perikelakuan yang diakui dan diterima oleh masyarakat. Kebiasaan tidak dianggap semata-mata sebagai cara berperikelakuan saja akan tetapi diterima sebagai norma-norma pengatur maka disebutlah kebiasaan tadi sebagai tata kelakuan. Kebiasaan pada masyarakat akan mencerminkan tingkah laku dalam kehidupan sehari-hari, baik kebiasaan dalam bermasyarakat maupun dalam melaksanakan kegiatan usahatani yang terjadi secara berulang-ulang. Adanya kebiasaan yang dilakukan oleh petani akan mengakibatkan efek yang positif maka akan berlanjut pada petani berikutnya. Kebiasaan yang telah mengkristal pada masyarakat memerlukan waktu yang lama sehingga menjadikan bentuk pengalaman bagi petani lain di dalam melakukan usahatani.

Menurut Notoadmojo (2003) mengatakan bahwa kemauan adalah dorongan dari dalam diri manusia yang lebih tinggi tingkatnya daripada insting, refleks, dan keinginan. Kemauan sudah disertai dengan pemikiran-pemikiran atau akal budi dalam mencapainya. Adapun ciri-ciri kemauan adalah a) Dorongan dari dalam untuk mencapai tujuan tertentu yang disadari dan dipertimbangkan masak-masak, b) Pertimbangan terjadinya kemauan bukan hanya pikir saja, tetapi perasaan, hubungan dengan kondisi lingkungan,sosial,ekonomi, dan sebagainya, dan c) Gejala kemauan akan diikuti oleh aktivitas tertentu yang disebut perbuatan,tindakan atau prilaku.

Kemauan terjadi melalui suatu proses yang tidak sederhana, karena kemauan didasarkan atau terjadi karena adanya dorongan yang kuat dari dalam diri manusia, dan melalui proses. Adapun proses yang dilalui adalah a) Adanya dorongan (Motif), yaitu suatu alasan-alasan sebelum berbuat ( justifikasi), b) Mempertimbangkan Motif, yakni 
mempertimbangkan alasan-alasan (berargumentasi), c) Memilih dan memutuskan, yakni memilih salah satu alternatif yang paling rendah resikonya dan d) Melaksanakan keputusan : perbuatan,tindakan,prilaku. Pada Tahap terakhir ini kemauan sudah menjadi kenyataan atau terwujud, dalam bentuk prilaku dan tindakan.

Berdasarkan uji statistik nonparametrik dengan menggunakan uji Zscore di peroleh nilai Nilai $Z$ tab ( $x=5 \% \mathrm{db}=-1,49)=0.4404$ maka di putuskan jika [Zhit] $=-1,49<Z$ tab $=0.4404$ maka di simpulkan tolak $\mathrm{H} 1$ (terima $\mathrm{H}$ ) yang berarti tinggi rendahnya pengaruh faktor kebiasaan dan kemauan petani padi sawah di pengaruhi oleh tinggi rendahnya keputusan petani dalam pemanfaatan lahan rawa lebak pada usahatani padi sawah.

\section{Pengalaman Petani}

Berdasarkan hasil penelitian yang dilakukan dapat di ketahui pengaruh faktor pengalaman petani terhadap keputusan petani dalam pemanfaatan lahan rawa lebak pada usahatani padi sawah adalah rendah. Lebih jelas pengalaman petani dapat di lihat pada tabel 3 berikut;

Tabel 3.Kontingensi Pengaruh Faktor Pengalaman Petani Terhadap Keputusan Petani Dalam Pemanfaatan Lahan rawa lebak Pada Usahatani Padi Sawah Di Daerah Penelitian 2013

\begin{tabular}{|c|c|c|c|c|}
\hline \multirow[t]{2}{*}{ Pengalaman } & $\begin{array}{l}\text { Keputusan } \\
\text { rawa lebak }\end{array}$ & Petani & Memanfaatkan lahan & \multirow[t]{2}{*}{ Total } \\
\hline & Rendah & & Tinggi & \\
\hline Rendah & 5 & & 34 & 39 \\
\hline Tinggi & 13 & & 13 & 26 \\
\hline Jumlah & 18 & & 47 & 65 \\
\hline
\end{tabular}

Tabel 3 memperlihatkan pengaruh faktor pengalaman petani dalam memanfaatkan lahan rawa lebak pada usahatani padi sawah yaitu tidak ada kecendrungan pengaruh faktor pengalaman petani dalam pemanfaatan lahan rawa lebak pada usahatani padi sawah di lihat pada tabel di atas dapat dilihat bahwa petani sampel yang terbanyak terkategori pengalaman dengan kategori rendah dan keputusan petani dalam memanfaatkan lahan rawa lebak tinggi dengan sebanyak 34 petani sampel.

Selanjutnya menurut Siagian (2009), pengalaman pahit tidak jarang menjadi kendala dalam mengambil keputusan dan bahkan sangat menghantui seseorang sehingga ia menjadi takut dan ragu-ragu dalam mengambil keputusan., artinya semakin banyak pengalaman seseorang makin berani dan memantapkan dia mengambil keputusan.

Pengalaman akan mempengaruhi kecakapan petani dalam mengambil keputusan dan menentukan alternatif dari keputusan tersebut. Semakin lama petani mengelola usahataninya maka diharapkan petani semakin rasional dalam mengambil keputusan sehingga dalam berusahatani akan semakin berhasil Soekartawi (2005).

Berdasarkan uji statistik nonparametrik dengan menggunakan uji Zscore di peroleh Nilai Z tab ( $x=5 \% \mathrm{db}=0,25)=0.4404$ maka diputuskan [Zhit] = 0,25 $<$ Ztab $=0.4404$ maka di simpulkan tolak $\mathrm{H} 1$ (terima $\mathrm{HO}$ ) yang berarti tinggi rendahnya pengaruh faktor pengalaman 
petani padi sawah di pengaruhi oleh tinggi rendahnya keputusan petani dalam pemanfaatan lahan rawa lebak pada usahatani padi sawah.

\section{Pengetahuan Petani}

Faktor pengetahuan petani disini maksudnya adalah segala sesuatu yang di ketahui petani, apakah petani itu pernah mengikuti pelatihan atau kursus tentang pemanfaatan lahan rawa lebak, apakah tahu tentang bibit unggul dan mengetahui pemanfaatan lahan rawa lebak melalui media televisi,radio,dll.

Hasil penelitian dilapangan terlihat bahwa pengetahuan petani mempunyai pengaruh besar terhadap pengambilan keputusan petani dalam pemanfaatan lahan rawa lebak pada usahatani padi sawah hal ini dapat dilihat pada tabel 4 di bawah ini.

Tabel 4.Kontingensi Pengaruh Faktor Pengetahuan Petani Terhadap Keputusan Petani Dalam Pemanfaatan Lahan rawa lebak Pada Usahatani Padi Sawah Di Daerah Penelitian 2013

\begin{tabular}{llll}
\hline \multirow{2}{*}{ Pengetahuan } & \multicolumn{2}{l}{$\begin{array}{l}\text { Keputusan Petani Memanfaatkan lahan rawa } \\
\text { lebak }\end{array}$} & Total \\
\cline { 2 - 3 } & Rendah & Tinggi & \\
\hline Rendah & 11 & 9 & 20 \\
Tinggi & 7 & 38 & 45 \\
\hline Jumlah & 18 & 47 & 65 \\
\hline
\end{tabular}

Tabel 4 memperlihatkan pengaruh faktor pengetahuan petani terdapat kecendrungan dalam pemanfaatkan lahan rawa lebak untuk usahatani padi sawah di karenakan, dilihat tabel di atas tingginya faktor pengetahuan petani terhadap keputusan petani dalam pemanfaatan lahan rawa lebak pada usahatani padi sawah terdapat 38 petani sampel yang menjawab faktor pengetahuan petani dengan kategori tinggi sedangkan keputusan petani dengan rata-rata tinggi.

Pengetahuan seseorang tentang keadaan dimana dia membuat keputusan juga mempengaruhi keputusan-keputusan yang akan dibuatnya (Bishop, 1979). Petani yang tidak banyak pengetahuan dan hidup dalam lingkungan masyarakat desa yang mempunyai pengaruh besar terhadap seluruh hidupnya, pada umumnya kurang berani menghadapi resiko dan oleh karenanya mereka tetap pada usahatani yang paling aman yang dari dulu ia usahakan.

Pengetahuan memberi landasan bagi keinginan untuk melaksanakan sesuatu (Koenjaraningrat, 2009). Artinya petani memikirkan ancaman kedepan bila terjadi krisis pangan hal yang akan dilakukannya adalah pemaanfaatan lahan rawa lebak untuk percetakan sawah baru karena bisa menambah produksi padi meningkat dari produksi sebelumnya.

Berdasarkan uji statistik nonparametrik dengan menggunakan uji $Z_{\text {score }}$ di peroleh nilai $Z_{\text {hit }}=1,24$ dengan nilai $Z_{\text {tab }}(x=5 \% \mathrm{db}=1)=0.4404$ maka di putuskan jika $\left[Z_{\text {hit }}\right]=1.24>$ $Z_{\text {tab }}=0.4404$ maka di simpulkan tolak $\mathrm{H}_{\mathrm{o}}$ (terima $\mathrm{H}_{1}$ ) yang berarti tinggi rendahnya pengaruh faktor pengetahuan petani padi sawah di pengaruhi oleh tinggi rendahnya keputusan petani dalam pemanfaatan lahan rawa lebak pada usahatani padi sawah. 


\section{Motif Ekonomi}

Motif ekonomi seperti pendapatan sebelum atau sesudah memanfaatkan lahan rawa lebak untuk usahatani padi sawah sangat mempengaruhi keputusan petani dalam pemanfaatan lahan rawa lebak untuk usahatani padi sawah karena menurut petani berusahatani padi sawah dapat memenuhi kebutuhan hidupnya sehari-hari,dan hasil panen tahun 2012 cukup dan puas untuk memenuhi kebutuhan hidupnya setelah musim panen berikutnya. Untuk lebih jelas lagi dapat dilihat pada table 5 . Berikut ini.

Tabel 5.Kontingensi Pengaruh Faktor Motif Ekonomi Terhadap Keputusan Petani Dalam Pemanfaatan Lahan rawa lebak Pada Usahatani Padi Sawah Di Daerah Penelitian 2013

\begin{tabular}{llll}
\hline \multirow{2}{*}{ Motif Ekonomi } & \multicolumn{2}{l}{$\begin{array}{l}\text { Keputusan Petani Memanfaatkan lahan rawa } \\
\text { lebak }\end{array}$} & \multirow{2}{*}{ Total } \\
\cline { 2 - 3 } & Rendah & Tinggi & 15 \\
\hline Rendah & 8 & 7 & 50 \\
Tinggi & 10 & 40 & 65 \\
\hline Jumlah & 18 & 47 & \\
\hline
\end{tabular}

Tabel 5 memperlihatkan pengaruh faktor motif ekonomi terdapat kecendrungan dalam mamanfaatkan lahan rawa lebak untuk usahatani padi sawah di karenakan, dilihat dari tabel di atas tingginya faktor motif ekonomi petani terhadap keputusan petani dalam pemanfaatan lahan rawa lebak pada usahatani padi sawah terdapat 40 petani sampel yang menjawab faktor motif ekonomi dengan kategori tinggi sedangkan keputusan petani dengan rata-rata tinggi.

Ahli-ahli psikologi berpendapat bahwa dalam diri individu ada sesuatu yang menentukan perilaku, yang bekerja dengan cara tertentu untuk mempengaruhi perilaku tersebut. Ada yang menyebut penentu perilaku tersebut dengan istilah kebutuhan atau "need" dan ada yang menyebutnya dengan istilah motif atau motivasi (Martaniah, 1984).

Menurut Gerungan dan Ahmadi (1990), motif ekonomi merupakan suatu pengertian yang melengkapi semua penggerak alasan-alasan atau dorongan dalam diri manusia yang menyebabkan ia berbuat sesuatu.

Menurut Bishop dan Toussaint (1979) mengatakan pendapatan petani dapat dipengaruhi oleh pemilihan mereka atas hasil produksi, dimana pemilihan hasil produksi tersebut dilakukan sebagian besar petani berdasarkan pendapatan yang mereka harapkan dan penjualan hasil produksi yang diusahakannya.

Berdasarkan uji statistik nonparametrik dengan menggunakan uji $Z_{\text {score }}$ di peroleh nilai $Z_{\text {hit }}=1.7$ dengan nilai $Z_{\text {tab }}(x=5 \% \mathrm{db}=1)=0.4404$ maka di putuskan jika $\left[Z_{\text {hit }}\right]=1.7>Z_{\text {tab }}$ $=0.4404$ maka di simpulkan tolak $\mathrm{H}_{\mathrm{o}}$ (terima $\mathrm{H}_{1}$ ) yang berarti tinggi rendahnya pengaruh faktor pengetahuan petani padi sawah di pengaruhi oleh tinggi rendahnya keputusan petani dalam pemanfaatan lahan rawa lebak pada usahatani padi sawah.

Pengaruh Faktor-Faktor Terhadap Pengambilan Keputusan Dalam Pemanfaatan Lahan rawa lebak. 
Petani sebagai pemilik lahan yang memutuskan untuk pemanfaatan lahan rawa lebak pada usahatani padi sawah adalah memilih alternatif terbaik yang dapat memberikan kesempatan memperoleh hasil yang diinginkan.Persoalan utama yang perlu di uji adalah faktor-faktor yang mempengaruhi pengambilan kekeputusan petani dalam pemanfaatan lahan rawa lebak. Komoditi keputusan petani dalam memanfaatkan lahan adalah komoditi padi sawah, maka dari komoditi yang diusahakan akan membawa keuntungan yang maksimal. Untuk itu perlu adanya evaluasi potensi penanaman yang akan di usahakan yang menyangkut masalah keputusan petani. Proses pemanfaatan lahan rawa lebak pada usahatani padi sawah merupakan prilaku petani yang berhubungan dengan keputusan yang rasional sebagai usaha untuk memenuhi dan meningkatkan kebutuhan hidupnya.

Persoalan inilah yang harus di uji apakah ada pengaruh faktor-faktor keputusan petani dalam pemanfaatan lahan rawa lebak. Untuk lebih jelasnya dapat dilihat pada tabel 6.

Tabel 6.Kontingensi Pengaruh Faktor-faktor Terhadap Pengambilan Keputusan Petani Dalam Pemanfaatan Lahan rawa lebak Pada Usahatani Padi Sawah Di Daerah Penelitian 2013

\begin{tabular}{llll}
\hline \multirow{2}{*}{ Keputusan Petani } & \multicolumn{2}{l}{ Faktor-Faktor Yang Mempengaruhi } & \multirow{2}{*}{ Total } \\
\cline { 2 - 3 } & Rendah & Tinggi & 20 \\
Rendah & 9 & 11 & 45 \\
Tinggi & 9 & 36 & 65 \\
\hline Jumlah & 18 & 47 & \\
\hline
\end{tabular}

Memperlihatkan pengaruh faktor-faktor petani terhadap keputusan petani dalam memanfaatkan lahan rawa lebak pada usahatani padi sawah terdapat pengaruh nyata karena dilihat dari tabel 6 bahwa keputusan petani berkategoti tinggi dan keputusan petani dalam pemanfaatan lahan rawa lebak juga berkategori tinggi. Hal ini memperlihatkan apabila faktor-faktor petani tinggi terhadap keputusan petani dalam pemanfaatan lahan rawa lebak berarti terdapat pengaruh faktor-faktor petani dalam memanfaatkan lahan rawa lebak tinggi. Menurut Drucker dalam Salusu, (2006) Pengertian keputusan (decision) berarti pilihan (choice), yaitu pilihan dari dua atau lebih kemungkinan. McGrew dan Wilson dalam Salusu, (2006) lebih melihat pada kaitannya dengan proses pengambilan keputusan yaitu keadaan akhir dari suatu proses yang lebih dinamis, sedangkan Morgan dan Cerullo (1984) sebagai sebuah kesimpulan yang dicapai sesudah dilakukan pertimbangan, yang terjadi setelah satu kemungkinan dipilih, sementara yang lain di kesampingkan. Dalam hal ini, yang dimaksud dengan pertimbangan ialah menganalisis beberapa kemungkinan atau alternatif,sesudah itu dipilih satu diantaranya. Direncana atau disetujui dengan menjatuhkan pilihan pada salah satu alternatif pemecahan masalah.

Pengambilan keputusan adalah pemilihan alternatif prilaku ( kelakuan) tertentu dari dua atau lebih alternatif yang ada. Menurut Salusu, (2006) pengambilan keputusan ialah proses memilih suatu alternatif cara bertindak dengan metode yang efisien sesuai situasi. Pernyataan ini menegaskan bahwa mengambil keputusan memerlukan satu seri tindakan, membutuhkan beberapa langkah, langkah-langkah itu terdapat dalam pikiran seseorang yang sekaligus mengajaknya berfikir sistematis, Inbar dalam salusu,(1996) Pengambilan keputusan hendaknya dipahami dalam dua pengertian yaitu penetapan tujuan yang 
merupakan terjemahan dari cita-cita, aspirasi dan mencapai tujuan melalui implementasinya.

Keputusan adalah pilihan tentang apa yang di anggap sebagai pemecahan masalah, setelah melihat fakta nilai dilapangan yang merupakan implementasi visi misi yang dikehendaki, di rencana atau disetuju dengan menjatuhkan pilihan pada salah satu alternatif pemecah masalah. Keputusan pada dasarnya adalah pilihan yang secara sadar dijatuhkan pada salah satu alternatif dari berbagai alternatif yang tersedia (Siagian, 2009). Satu hal yang amat penting dalam proses pengambilan keputusan ialah adanya keterkaitan langsung antara tindakan yang diambil dengan tujuan dan berbagai sasaran yang ingin dicapai, artinya tujuan dan sasaran dari pada keputusan adalah fakta penting yang sangat mempengaruhi seseorang itu mengambil keputusan tersebut atau tidak. Proses pemikiran itu dimulai dengan motivasi yang dialami orang setelah melihat sesuatu. Adapun penglihatan atas sesuatu itu tergantung dari dunia kondisi orang masing-masing.

Menurut Atmosudirdjo (1987) dalam Syamsi (2000) menyatakan bahwa sistem dimana proses proses pengambilan keputusan berlangsung terdiri atas berbagai unsur dan masing-masing merupakan faktor yang menentukan keputusan. Faktor disini adalah faktor yang mendorong petani pengambilan keputusan untuk pemaanfaatan lahan rawa lebak pada percetakan sawah baru atau pada usahatani padi sawah.

Kesimpulan petani sebagai pemilik lahan yang memutuskan untuk pemanfaatan lahan rawa lebak pada usahatani padi sawah dapat di tentukan oleh beberapa faktor yang mempengaruhi pengambilan keputusan, yaitu; kebiasaan dan kemauan,pengalaman, pengetahuan, dan motif ekonomi.

Berdasarkan uji statistik nonparametrik dengan menggunakan uji $Z_{\text {score }}$ di peroleh nilai $Z_{\text {hit }}=1.48$ dengan nilai $Z_{\text {tab }}(x=5 \% \mathrm{db}=1)=0.4404$ maka di putuskan jika $\left[Z_{\text {hit }}\right]=1.48>$ $Z_{\text {tab }}=0.4404$ maka di simpulkan tolak $\mathrm{H}_{\mathrm{o}}$ (terima $\mathrm{H}_{1}$ ) yang berarti tinggi rendahnya pengaruh faktor-faktor petani padi sawah di pengaruhi oleh tinggi rendahnya keputusan petani dalam pemanfaatan lahan rawa lebak pada usahatani padi sawah.

\section{KESIMPULAN}

Berdasarkan analisis deskriptif, bahwa faktor pengalaman petani tidak terdapat kecenderungan pengaruh terhadap pengambilan keputusan petani dalam pemanfaatan lahan rawa lebak pada usahatani padi sawah didaerah penelitian. Sedangkan faktor kebiasaan dan kemauan,faktor pengetahuan, dan faktor motif ekonomi terdapat kecenderungan pengaruh terhadap pengambilan keputusan petani dalam pemanfaatan lahan rawa lebak pada usahatani padi sawah di daerah penelitian.

Faktor yang berpengaruh dalam beberapa faktor yang telah di analisis ZScore dari faktor kebiasaan dan kemauan, faktor pengalaman petani,faktor pengetahuan, dan faktor motif ekonomi yang tergolong tinggi dan yang lebih dominan dan berpengaruh adalah faktor motif ekonomi.

\section{UCAPAN TERIMA KASIH}

Ucapan terimakasih disampaikan Kepada Kepala Desa Pasar Terusan beserta masyarakat Desa Pasar Terusan yang telah membantu memberikan informasi yang 
dibutuhkan, serta Dinas Pertanian Tanaman Pangan dan holtikultura yang telah memberikan data-data dan informasi yang dibutuhkan, serta Dinas Balai Penyuluhan Pertanian, Perikanan dan Kehutanan (BP3K) yang telah meberikan data-data yang di perlukan

\section{DAFTAR PUSTAKA}

Ahmadi.A dan W. Supriono (2004). Psikologi Belajar, Edisi Revisi. Jakarta: Rineka Cipta . Bishop, C.E dan W.D. Toussaint. 1979. Pengantar Analisa Ekonomi Pertanian. Mutiara. Jakarta.

Dharmawan. 2010. Inovasi Leisa FP, Teknologi Baru Meningkatkan Produksi Padi Dengan Biaya Rendah. Pustaka Pelajar. Jogjakarta.

Djarwanto, Ps, Drs, 1985. Statistik Nonparametrik. BPFE, Yogyakarta.

Koentjaraningrat. 2009. Pengantar Ilmu Antropologi (Edisi Revisi). Jakarta: Rineka Cipta.

Martaniah, S.M. 1984. Motif Sosial Remaja Suku Jawa dan Keturunan Cina dibeberapa SMA Yogyakarta: Suatu Studi Perbandingan,

Notoatmodjo, Soekidjo. 2003. Pendidikan dan Perilaku Kesehatan. Renika Cipta. Jakarta. Yogyakarta; Gajah Mada universitas Press.

Salusu.j.2006. Pengambilan Keputusan Stratejik. PT. Gramedia Widiasarana Indonesia, Jakarta.

Syamsi, Ibnu. Pengambilan Keputusan (Decision Making). Jakarta : Bina Aksara. 1989.

Siagian Sondang p. 1990. Sistem Informasi Untuk Pengambilan Keputusan. Haji masagung, Jakarta.

Sugiyono.2012. Statistika untuk Penelitian. Alfabeta. Bandung.

Soekartawi. 2005. Prinsip Dasar Komunikasi Pertanian. Universitas Indonesia, Jakarta. 